TABle I. CoRrections to Relative bearing of A bEACON For HeEl

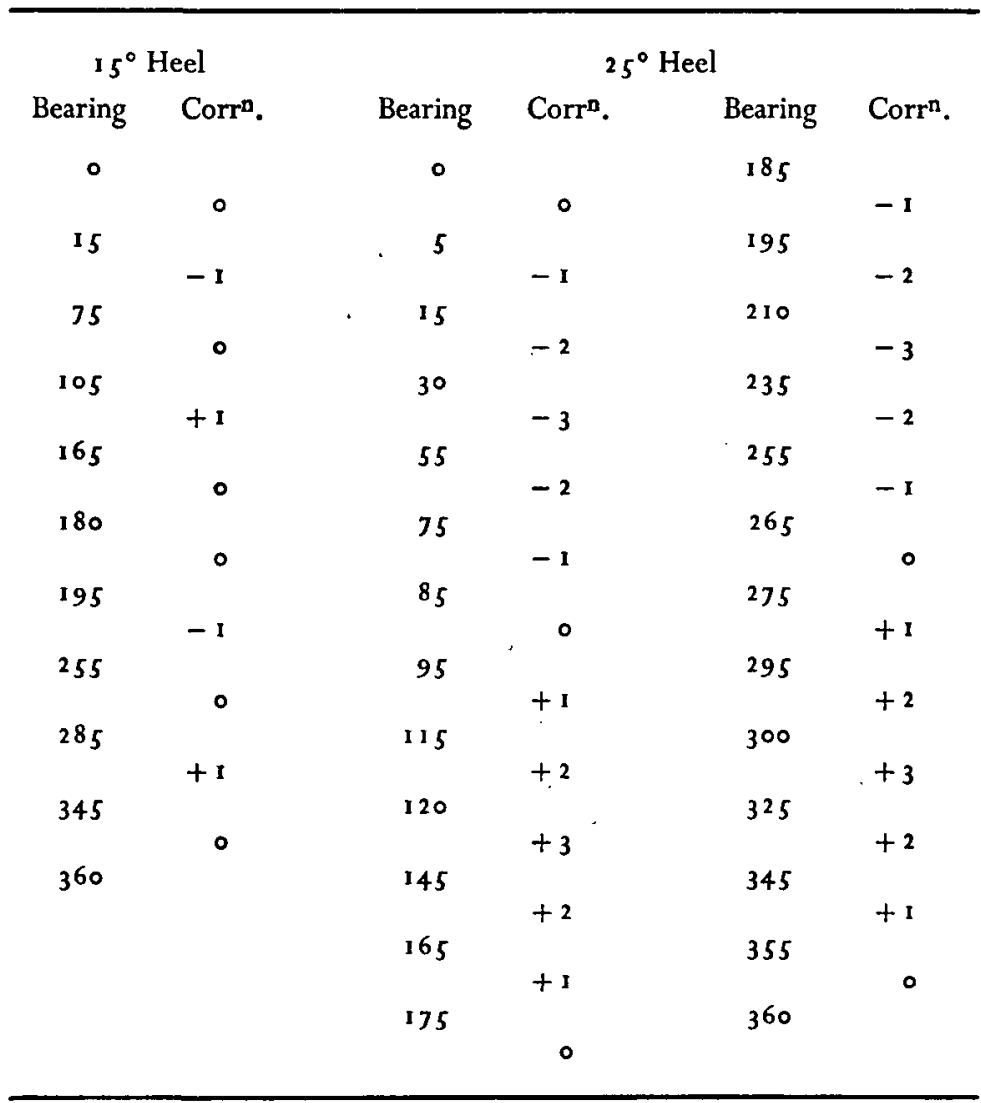

\title{
Plane Sailing or Horizontal Navigation
}

\author{
from Lieut.-Commander D. W. Waters, R.N.
}

PROFESSOR TAYLOR*. contends that the expression used to describe a course of action so simple as to leave no room for mistakes is plain sailing; that this is nautical in origin in that it derives from a simple or plain system of navigation based upon the use of a simple or plain (manifestly foolproof) chart; that this system of navigation was known originally as plain (simple) sailing-which expression she traces back to Richard Norwood's Doctrine of Plaine and Sphericall Triangles of 1631 , and that it was sophisticated into plane sailing in the eighteenth century in the belief-which she holds to be erroneous-that the expression described a form of navigation based upon the use of a plane or flat chart on which the Earth was drawn as if the Earth and oceans lay in one horizontal plane area and not upon the surface of a sphere or, more accurately, ellipsoid; and, finally, that the Admiralty Novigation Monual is in error in teaching mariners that

* Taylor, E. G. R. (1956) All plain sailing. This Journal, 9, 230. 
'to regard certain small triangles as plane ... gives rise to the expression plane sailing, which is popularly referred to as if plane were spelt plain and the sailing free from difficulty'.

There is plenty of sound evidence that, during the first two-thirds of the sixteenth century, English hydrographers were few, that their products were inferior to those of their Portuguese, Spanish, French and Dutch contemporaries, that English seamen rarely traversed the oceans, and that very few understood the art of navigation as developed and practised by continental seamen. In the I550's a number of English mariners began to be trained in the art. Their chief instructor was Sebastian Cabot. Before he was bribed to come over to England and teach Englishmen navigation Sebastian Cabot had been for many years head of the Spanish hydrographical office; he was also a very experienced navigator, and as Piloto-mayor had been responsible for the training, examination and licensing of all Spanish navigators. Amongst the English mariners successfully trained under Cabot was Stephen Borough. In the late I $55^{\circ}$ 's he became chief pilot (navigator) of the Muscovy Company and in this capacity visited the Casa da Contratación at Seville as a guest. The visit was possible because Prince Philip of Spain was married to Mary, Queen of England. Deeply impressed by what he saw of the Spanish hydrographical office and navigational system, Borough brought back with him a copy of Martin Cortes's Breve Compendio de la Sphera y de la Arte de Navegar written in 1545, first published at Seville in I $55 \mathrm{I}$, reprinted in 1556 . This work Richard Eden translated and published in London in $156 \mathrm{I}$ under the title The Arte of Navigation. It was the first book published in England on the subject. It was reprinted many times, the last edition appearing as late as 1630 . It might almost be termed the navigational 'bible' of English navigators over a period of some eighty years. This is what Cortes had to say of sea charts in the Spanish first (155I) and second (1556) editions of his work which he had actually finished writing in 1545 (I have given Eden's translation of 1561 ):

\section{CORTES}

\section{Defectos de la carta pintada en plano}

No usan ni saben usar los pilotos y marineros de otros cartas sino destras planas: (como dicho tẽgo) las quales por no ser globosas son imperfectas: y asi deran de señalar quequanto se van alongädo de la equinocial para qualquier de los polos las lineas meridianos se va restriñēdo y angostando de tal manera q̃ si dos cuidades o puntos en la equinoctial distassen de longitud sesenta leguas y en los mesmos meridianos a sesenta grados de la equinoctial para qualquier de los polos estoniese otros dos cuidodes o puntos: no distarian de longitud sino treinta leguas ... [sino] por las cartas planas $\bar{q}$ ay las mesmas... [sesenta] leguas $E$ sin estas y otras cõsideraciones im error acarrea otro y otro a otro: ospecificarlo aq' no solo seria para algunos pilotos (come dizen) dar musica al fordo o pintar casa pa ciegos mas aun seria meterlos en cõfusioo.

\section{EDEN}

\section{The playne cardes are imperfecte}

The Pilots and Mariners neither use nor have knowledge to use other Cardes but only those that are playne, as I have said. The which, because they are not globous, spherical or rounde, are imperfecte, and faile to show the true distances. For, in howe much they depart from the Equinoctiall towards whychesoever of the Poles, the Meridian lines are contracted narrower and narrower: In such manner, that if two Cities or poyntes in the Equinoctiall should be distant in longitude 60 leagues and in 
the self-same Meridian at 60 degrees from the Equinoctiall toward eyther Pole should be other two Cities or poyntes they should be distant in longitude but only 30 leagues ... [yet] by the plaine cardes they have the self-same ... [60] leagues. And besides these considerations one errour bringeth in another, so another another: wherof to speak any more heere it shall be to certeyne Pilots (as ye proverb saith) not only to give musyke to the deaf or to paynt a house for blinde men, but shall also be an endlesse confusion. [Spelling modernized but 'playne' and 'plaine' as spelt.]

From the foregoing it is evident that Eden rendered an accurate translation of Cortes's work, that he rendered 'cartas planas' into 'playne cardes' with the intention of conveying that, in modern parlance, they were 'plane charts' because, to use his words, they were not 'globous, spherical or rounde' but 'playne'-plane. Indeed he emphasized the point by rendering Cortes's 'globosas' as 'globous, spherical or rounde'. If Cortes had intended his reader to understand that he was describing a simple chart he would not have used the adjective 'plana' which means plane, flat, he would have had to have used a word such as 'clara' or 'sencilla' or 'simple'. Furthermore, he would not have headed his section, 'Defectos de la carta pintada en plano'-_'Defects of the chart drawn en plano' - on a plane surface. He would have to have written, 'Defectos de la carta pintada sin ambages', or some such phrase meaning defects of the plain (simple) chart. But nowhere does Cortes suggest that his cartas planas were simple, plain or foolproof to mariners, either in general or particular. In the section from which extracts have been given above he manages to convey the contrary impression, which his translator faithfully echoes. Moreover, in a preceding section in which he describes 'the making of the nautical chart' (la cõposiciõ de la carta de marear) Cortes states that 'clever men' (los ingenios de los hombres) have drawn the world on a bearing-and-distance chart with a latitude scale, and that he considers-not without reason-that agreement between the position of places charted by bearing and distance and by observation of the height of the pole required the highest hydrographical skill. Indeed he concluded that agreement was impossible in the higher latitudes with the result that in use plane charts were the cause of 'endless confusion' - the very antithesis of foolproof simplicity.

Nor was Cortes a lone. Spanish voice in speaking of 'cartas en plano'. His equally authoritative contemporary, Pedro de Medina whose Arte de Navegar of I 545 was read and approved by the Casa de Contratación before publication, also wrote of the drawing of 'la carta en plano' adding that the same quantity or distance that the ship's way measured 'en el redondo' (on the sphere) was shown 'en el plano' (on the plane superficies). (Fol. xxxi.) His work, very popular on the continent, was belatedly translated by John Frampton and published in England in ${ }_{5} 5^{8} \mathrm{I}$ as the Art of Navigation and was reprinted fifteen years later.

Similarly Pedro Nuñez, the greatest Portuguese hydrographical authority of the first half of the sixteenth century, and the man who first postulated the spiral nature of rhumb lines, discussed the plane chart in his Tratado da Sphera of 1537 , in unambiguous terms.

In short, when English seamen first learnt to navigate using plane charts as delineated by the continental hydrographers who originated them and who described them as 'plane', they too called the charts - no matter how they spelt the word-plane. Furthermore, they found the art of navigating by them anything but 'plain-sailing'. Indeed Stephen Borough, William Bourne, Thomas 
Digges, all good authorities, make it quite clear that the majority of English pilots in the $155^{\circ}$ 's, $1560^{\prime}$ 's, and a good few in the 1570 's, looked upon navigation based upon the use of a plane chart as a black art. Nor when it came to navigating in the higher latitudes were they far wrong-as Cortes suggested. The plane chart in the sixteenth and seventeenth century was by no means always as simple a 'plan' as Professor Taylor's brief description of it suggests. The bearing-anddistance chart of the fifteenth and earlier centuries had added to it at the close of the fifteenth century a single latitude scale. From the start of the sixteenth century hydrographers found that it was impossible to reconcile all positions on a bearing and distance chart covering a large area-such as the Mediterranean or Atlantic-to a single latitude scale. They therefore introduced double latitude scales and even three latitude scales, and oblique meridians with latitude scales on them, each innovation being an attempt to reconcile the charted positions plotted by compass bearing and distance with the charted positions plotted by astronomical observation (latitude only). The earliest known plane chart with a longitude scale is dated 1529 and though such charts do not seem to have been common they were thenceforth made.

In time it came to be recognized that one cause of position discrepancies in plane charts lay in the practice of plotting positions by compass bearing uncorrected for variation. As this phenomenon of variation began to be better understood the most experienced and best instructed navigators began to determine variation and apply the correction to their observations, and hydrographers followed suit. But variation bedevilled navigation and hydrography until the middle of the seventeenth century. William Borough writing in the I 580 's had a lot to say on the problems of variation and hydrography, double latitude scales, oblique meridians, and the difficulties of navigating on the plane chart that they involved, quite apart from those arising from the admittedly erroneous practice of drawing the plane charts with equidistant parallels of latitude and meridians of longitude.

William Bourne, in his Rules of Navigation of 1567 and 1571 , included a rule 'how to sail by the globe'. He did so because 'the most part of the seamen make their accompt', he explained, 'as though that the earth were a platte forme'. They did so, he further explained, because it was the only known way of drawing 'the face of the earth and the sea upon a platte forme', i.e. a plane surface.

Wright solved the problem of a true representation of the Earth on a plane surface with his 'Table for the true dividing of the Meridians in the Sea Chart' of 1599 . With this table, what he termed 'the nauticall Planisphere or Sea Chart', a chart drawn on a 'plaine superficies'-flat surface-could be drawn in which, as he put it, 'the distances of the Parallels from the equinoctial towards the Poles were increased in such sort that, at every point of latitude in the Chart, a part of the Meridian had the same proportion to the like part of the Parallel that it had in the globe'. Incidentally Wright called the plane chart the 'common sea chart' or the 'ordinary sea chart' and described it 'in many places much like an inextricable labyrinth of error, out of which it will be very hard for a man easily to unwinde himself'.

Blundeville, a very reputable Elizabethan authority on navigational practice, described 'The Mariners Card, which some call a Nautical Planisphere', as 'none other thing than a description made in Plano upon paper or parchment of the places that be in the Sea or in the land next adjoining to the Sea'. This was 
in his Exercises of 1594. Captain John Davis published in this same year his long popular Seamans Secrets. He was the first English author to distinguish three kinds of navigation or sailing. These he termed 'Horizontal', or 'Paradoxal or Cosmographical', and 'Great Circle Navigation'. 'Horizontal navigation manifests all the changes of the Ship's motion within the Horizontal plain superficies, where every line drawn is supposed a parallel', he wrote, describing, in fact, plane sailing. Paradoxal navigation he defined as, 'navigation which shows the true motion of the ship upon any Course assigned in longitude, latitude and distance and is the skilful gathering together of many Horizontal Courses into one true motion Paradoxal'; that is to say it was navigation on a 'Paradoxal' or Circumpolar chart. The phrase 'a true motion Paradoxal', meant 'a true rhumb line course and distance', a true rhumb line having been termed by Dr. Dee, Davis's instructor, a 'paradoxal line' because of its spiral nature on the globe and circumpolar chart. Davis's definition of paradoxal sailing suggests that he used Dr. Dee's solution of the nautical triangle recently described by Professor Taylor. Wright's solution of the Mercator chart, included in summary form in Blundeville's Exercises of 1594 he does not mention. In his preface of 1599 to Certaine Errors in Navigation Wright described Mercator's sailing in words and phrases similar to those used by Davis to describe 'paradoxal' navigation, and, indeed, it can fairly be described as the forerunner of Mercator's sailing.

Cortes's and Blundeville's works continued in current use into the middle, Davis's and Wright's into the latter half of the seventeenth century. Captain Samuel Sturmy in his long-popular Mariners Magazine of 1669 waxed eloquent upon the 'Uncertainties of sailing by the Plain Chart', devoting his fourth book to the subject. The Seaman's Tutor of 1682, a navigational text-book written especially for the recently instituted navigational students of Christ's Hospital, carried on Davis's practice of describing three kinds of sailing 'Plain', 'Mercator's' and 'Great Circle', under the heading of 'The Division of Navigation according to the Chart'.

'The first,' the student learnt, 'is called Plain Sailing, manifesting all the varieties of the ship's motion on a Plain, where all the Meridians are made parallel, and the Parallels at right angles to the Meridians, and the degrees of each Parallel equal to those of the Equator, which tho notoriously false in itself, supposing the Earth and Sea to be a plain flat, ... '

Mercator's, the student learnt, 'demonstrateth also on a Plain ...' The meaning of this expression he could not misinterpret as, earlier in the book, he had learnt that, 'A Triangle is either Plain or Spherical', and that 'a plain triangle is that which is described on a plain Surface', a statement which also surely robs the title of Richard Norwood's The Doctrine of Plaine and Sphericall Triangles, of $163 \mathrm{I}$, of any ambiguity even if the contents of that work do nota question that will be examined shortly. Samuel Newton, late master of the Mathematical School at Christ's Hospital was equally clear in his Art of Navigation of 17 I 5 that, "The whole Art of Navigation consisteth in the application of Plain and Spherical Triangles' by 'sailing upon the Plain and True Sea Chart ... . by Plạin Triangles ...'

John Seller's Practical Navigation (1718 ed.) introduced the subject by way of 'Plain Triangles and Trigonometry', 'Right-angled and Oblique PlainTriangles and Spherical Triangles', and so led on to the 'Doctrine of Plain Triangles applied to Problems of Plain and Mercator's Sailing', the latter being solved on a Mercator's chart which, 'Although projected upon a Plain', \&c. 
Henry Wilson's Navigation New Modell'd of 1723 (first edition I 7 I 4 ) described 'the Solution of five cases of Plain Sailing, or any other Operation that depends upon right-angled plain Triangles', by means of Geometry, Trigonometry, Traverse Tables, Arithmetical Calculation and Instrumental manipulation, the five cases being Plain, Traverse, Mercator's, Parallel, and Middle Latitude sailing.

The earliest English authority to define and use the word 'plane' known to the present writer is Robert Norton. In his Mathematicall Appendix ... for Mariners at Sea ... (London, 1604) he discusses dialling and other astronomical observations and consistently uses in their modern sense the words 'plane' and 'plane superficies' or 'plane surfaces'. Furthermore, lest his readers should be in any doubt about the significance of the various mathematical words and phrases employed Norton appended a list of definitions. The definition of 'Plane' follows immediately upon that of 'A Superficies or Surface', as given below.

'A Superficies or Surface hath onely length and bredth without deepnesse'.

'A Plane is equally flat, contained within lynes, and doth not bulke out or shrinke at any place; and is saide to be represented, when a lyke figure hath an absolute lyke situation and constitution'.

When Richard Norwood wrote his Trigonometrie, Or The Doctrine of Triangles ... Whereunto is annexed... A Treatise of the application thereof in the three principall kindes of sailing... (London, I631), which Professor Taylor referred to as the original source of 'plain (as distinct from 'plane') sailing', Norwood classified his three kinds of sailing under the headings of:

(I) Questions of sayling by the plaine or ordinary sea-chart.

(2) Of Sayling by Mercators Chart.

(3) Problems of sayling by a great Circle.

Of 'sayling by the plaine or ordinary sea-chart' Norwood had this to say: 'Although the ground of the projection of the ordinary sea-chart being false, (as supposing the earth and sea to be a plaine superficies) and so the conclusions thence derived must also for the most part be erroneous: yet because it is most easie and much used, and the errours in small distances not so evident, we will not wholly neglect it'.

In the light of Robert Norton's definition of a 'plane superficies or surface' published more than a quarter of a century earlier it seems clear that by 'the plaine or ordinary sea-chart' Norwood-and other English writers of those times who used similar words and phrases-confidently believed that they would be understood by their contemporaries and by posterity to be discussing 'plane charts', charts which the original Spanish authorities described as 'pintada en plano' or 'cartas en plano', and whose projection 'supposed', to use Norwood's words, 'The earth and sea to be a plaine superficies', i.e. in the terminology of his contemporary Norton, 'a plane surface'.

Enough authorities have been cited to show that John Robertson, and William Wales, who included a beautifully engraved 'PLANE CHART' in the I 780 (fourth edition) of the Elements of Navigation, did not sophisticate 'plain chart' and 'plain sailing' into 'plane chart' and 'plane sailing'; that they merely, at long last, rationalized the English spelling of plane, taking as a basis (whether they knew it,or not), the original and unambiguous Spanish word 'plana'. If we allow for their rather pedantic phraseology we can also exonerate them from the 
suggestion "that the plain (sic) chart was drawn on the "notion" that the Earth was a plane', i.e. the 'belief' that it was a plane. Two centuries before they wrote, Bourne $(1567)$ had indeed stated 'that generally the most part of seamen make their accompt as though that the earth were a platte form, for they do not consider that the earth is a globe, and that the Meridians do grow narrower and narrower towards the two poles, for it is impossible to draw the face of the earth and the sea true upon a platte forme'. While most English seamen, from looking at their plane charts may, as Bourne averred, have believed the Earth was flat, we know from Cortes (to cite no other authorities) that the hydrographers who drew the charts knew otherwise. While Robertson and Wales ( 1780 ) indeed wrote on p. 6 'Plane sailing is the art of navigating a ship upon principles deduced from the notion of the Earth's being an extended plane', on p. 3 they had already written: 'There are many ways of constructing Maps and Charts; but they chiefly depend on two principles, First, From considering the Earth as a large extended flat surface: The Charts made on this supposition are usually called Plane Charts. Secondly, From considering the Earth as a sphere: The Charts made on this principle are sometimes called globular ...'

From this it seems clear that they were using the word 'notion' in the sense of 'on the concept (for the purposes of drawing a chart) of the Earth's being an extended plane'. This is given support by the opening of the chapter on 'Globular Sailing' (p. 13 I) which runs: 'In the preceding parts of sailing, the operations were performed as if the courses and distances of ships had been run on a plane, or flat surface ...'

Incidentally, like the authors of the modern Admiralty Navigation Manual, the authors of The Elements of Navigation discussed the problem of the Earth's true shape as 'the reasons and conclusions' they had used, 'had been delivered in the opinion that the Earth is a sphere' whereas, in fact, 'many observations made since $167^{2}$ ' showed that the 'polar diameter is shorter than the equatorial diameter'. They concluded, however, that for all practical purposes the Earth, though a 'spheroid or some more compounded figure' could be treated as a sphere, and that plane charts 'made for a small part may be reckoned as tolerably exact', and in the equatorial zone 'will differ but little from the truth'.

There remains the question of the origin of the expression 'plain sailing' as the description of a foolproof course of action.

The Oxford English Dictionary deals with the words 'plain' and 'plane' at very considerable length.

Of 'plane' it considers that it was introduced from the Latin plān-um, a flat surface, in the seventeenth century to express geometrical and allied uses, which had been from the sixteenth century (and were often down to the eighteenth) expressed by the historical form 'plain'. It cites Sir Thomas Browne as a user of plane ( 1646 ). Norton, it has been shown, was using it over forty years before.

Of 'plain', also from the Latin plän-um, the O.E.D. gives as one meaning, 'a level or flat surface, now spelt plane', and cites its belated use in this sense by Smeaton (1793) engineering the Eddystone Lighthouse, and a certain poet, Worsley (1863), describing the 'plains of two huge valves'.

Of 'plain sailing' it observes that it is 'probably a popular use of Plane Sailing, formerly also spelt plain sailing', when used in the sense of a simple course of action, and it defines 'plane sailing' as, 'The art of determining a ship's place on the theory that she is moving on a plane', and 'using a plane chart 
on which the meridians and parallels of latitude are represented by equidistant straight lines'.

The first use of the expression 'plain sailing' as a metaphor for a simple course of action the O.E.D. traces to the year 1827 when a certain Steuart, wrote in the 'Planter's G. (I 828 ) 493': 'It must be all "plain sailing", as the seamen say, and no sudden turns, intricacies or narrow passes'. Now it will be observed that the author was evidently a landsman, and furthermore that, unless he was in the habit of using obsolescent forms of spelling, he was misquoting the seamen of his day who always used the phrase 'plane sailing', though I know of no evidence supporting the view that they used it in the sense in which he supposed.

The next authority cited by the O.E.D. as using the expression 'plane sailing' as a metaphor for foolproof action is also a landsman. In this instance a certain 'Gen. P. Thompson' who wrote in 1858 : 'The motion at first looks as if it was all what sailors call plane sailing'. On this occasion the author, it will be noted, used the correct spelling if not the correct significance.

However, nine years later, we find-for the first time-a naval authority expanding upon the colloquial use of the phrase 'plane sailing'. This is Admiral W. H. Smyth, in his authoritative The Sailor's Word-book (London, 1867). After defining plane-sailing as 'That part of navigation that treats a ship's course as an angle, and the distance, difference of latitude, and easting or westing, as the sides of a right-angled triangle', for which conversion into difference of longitude is needed, he adds, 'Plane-sailing is so simple that it is colloquially used to express anything so easy that it is impossible to make a mistake'. Thus even if we accept this definition at its face value we have still to recognize that the original form of the modern expression 'all plain sailing' was 'all plane sailing' or 'horizontal navigation'.

It is by no means uncommon for an expression which passes out of that common use which keeps it alive and is its raison d'etre to become corrupted through disuse and misuse in some other rôle for which it was never coined. Plane-sailing is as good an example as any. The very book-Wales' and Robertson's Elements of Navigation-which firmly established the-then-modern method of spelling 'plane-sailing' also sounded the first notes of plane sailing's death knell. On p. 291 it discussed how 'to find the longitude by the help of a perfect time-keeper', explained the significance of the 'extraordinary inventions' of 'that very excellent artist, Mr. John Harrison' and expressed the belief that watches such as his 'may hereafter become more common, and be afforded for less than $100 £$ or a fourth part of their present value'. When that happened, as it quickly did, navigation entered a new era. At the very time that 'plainsailing' was being bandied about on shore as a metaphor for foolproof action, plane-sailing was falling into desuetude at sea as Mercator charts, their value enormously enhanced by the means of accurately determining longitude at sea, finally supplanted plane charts for all the waters of the world.

\section{Professor Taylor comments :}

The Oxford English Dictionary, like the Admiralty Manual, followed John Robertson, and is in fact rarely very useful in respect of scientific or technical terms. The craft of chart making, i.e. plotting bearings and distances on parchment or paper, came down with little change from thirteenth-century Italy, 
and was unrelated to 'notions' about the Earth. Projected maps, based in theory on astronomical fixes, began to be drawn in the late fifteenth and early sixteenth centuries. All maps are 'plane' in Cortes' sense, i.e. they are drawn on a flat, instead of a globular surface. They are therefore all imperfect, and the fact that maritime charts failed to show the convergence of the meridians was constantly stressed. Mercator's is a 'plane chart'. But it does not give 'a true representation of the Earth on a plane surface' as Lieutenant-Commander Waters states. It grossly distorts the shape of the continents, yet provided one has a table of meridional parts, it can give correct information about direction and distance. The term 'plane' was used in its correct geometrical sense by diallists, but Eden had no mathematics and writes 'playne'. The ambiguity of 'plaine or ordinary' I sufficiently demonstrated, but my 'as though' they were synonymous was printed as 'although'.

\section{The Plane Sailings}

\section{from C. H. Cotter}

IF a 'sailing' is defined as a means of finding by calculation, tables or construction, either: (a) the course and distance from one place to another, or $(b)$ the position of arrival after making a given course and distance from a given position, then what is commonly known as 'plane sailing' is not in this sense, a sailing at all. 'Plane' or 'Plain' sailing according to modern as well as early usage involves the arguments, distance, $d$. lat., departuse and course angle, and in order to solve the problems $(a)$ or $(b), d$. long., and either meridional $d$. lat. or 'middle' (not 'mean') latitude must enter the solution.

When a ship sails along any rhumb line except a meridian or parallel of latitude, the distance sailed, the $d$. lat. between the initial and final positions, and the departure between the initial and final positions, may be regarded as the sides of a plane right-angled triangle, the angle opposite the side representing departure being equal to the course angle. This plane triangle is essentially an artifice which shows the trigonometrical relationships between the arguments involved. These relationships are now known as the plane sailing formulae, namely:

$$
\begin{aligned}
\text { departure } & =\text { distance } \times \text { sine course } \\
d . \text { lat. } & =\text { distance } \times \text { cosine course } .
\end{aligned}
$$

Now it is a common belief amongst navigators that this artifice represents a triangle on the Earth's surface. This belief is strengthened by such definitions as'plane sailing is the art of navigating a ship on the supposition that the Earth is an extended plane'. Because the Earth is spherical no triangular area on its surface, however small, can be a plane triangle, but the somewhat false argument put forward is that the smaller is a triangle on the Earth, the more nearly is it plane. The question then arises as to what is the limiting distance sailed for assuming such a triangle to be plane? The distance that springs to the minds of many navigators is 600 miles-presumably because the traverse table extends to this figure in the distance column. A certain confusion arises when the distance involved exceeds 600 miles. 